\title{
HJKK
}

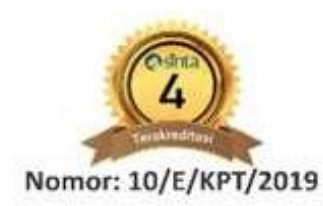

INFORMASI ARTIKEL

Received: August, 20, 2019

Revised: June, 27, 2021

Available online: June, 28, 2021

at : http://ejurnalmalahayati.ac.id/index.php/holistik

\section{Analisa pola asuh orang tua dengan harga diri pada siswa/siswi Sekolah Menengah Atas}

\section{Mardhatilah Hasdianasari ${ }^{1}$, Teguh Pribadi2*, Lolita Sary ${ }^{3}$}

${ }^{1}$ Rumah Sakit Jiwa Daerah Provinsi Lampung

2Program Studi Ilmu Keperawatan, Fakultas Kedokteran Universitas Mahalayati.

3Program Studi Kesehatan Masyarakat, Fakultas Kesehatan Masyarakat Universitas Mahalayati

Korespondensi Penulis: Teguh Pribadi. *Email: teguh@malahayati.ac.id

\section{Abstract}

\section{Analysis of patterns of parenting and self-esteem among high school students}

Background: Low self-esteem is a feeling of worthlessness. Family is one factor that determines an adolescent's personality. The form of adult parenting improves the child's personality when he is an adult.

Purpose: To an analysis of patterns of parenting and self-esteem among high school students

Method: Quantitative research with time research in a cross-sectional study. The population in this study were grade X high school students at Bandar Lampung in 2019 with a sample of 198 respondents. The instrument of data collection in this study used a questionnaire. Data analysis using Chi-Square test.

Results: The findings, most of the respondents were male, namely $173(87.4 \%)$, respondents who had low selfesteem were $70(35.4 \%)$, felt that their father was dominant in providing care $135(68.2 \%)$, respondents Those who feel they have authoritarian parenting are $33(16.7 \%)$, permissive parenting is $27(13.6 \%)$, neglected parenting is $44(22.2 \%)$, undemocratic parenting is $104(82.5 \%)$ and ( $p$-value $=0.000$ and $O R=4.143)$, ( $p$-value $=0.984)$, $(p$-value $=0.00$ and $O R=4.100)$, $(p$-value $=0.000$ and $O R=7.556)$.

Conclusion: There is a relationship between authoritarian parenting, neglect, and self-esteem among high school students. There is no relationship between permissive parenting and self-esteem among high school students. Suggestions: School management and psychological counseling to pay attention more to the importance of parenting that deserves high self-esteem in adolescents.

\section{Keywords $\quad$ : Patterns of parenting; Self-esteem; High school students}

Pendahuluan: Harga diri rendah adalah perasaan tidak berharga, tidak berarti dan rendah diri yang berkepanjangan akibat evaluasi yang negatif terhadap diri sendiri atau kemampuan diri. Keluarga merupakan salah satu faktor yang mempengaruhi kepribadian seorang remaja. Bentuk pola asuh orangtua mempengaruhi pembentukan kepribadian anak saat dia dewasa.

Tujuan: Untuk mengetahui hubungan pola asuh orang tua dengan harga diri pada siswa di SMK "A" Kota Bandar Lampung Tahun 2019.

Metode: Jenis penelitian ini adalah kuantitatif dengan pendekatan waktu dalam penelitian ini secara cross sectional. Populasi dalam penelitian ini adalah seluruh siswa kelas X di SMK A Bandar Lampung pada tahun 2019 dengan jumlah sampel 198 orang. Instrumen pengumpulan data dalam penelitian ini menggunakan kuesioner. Analisa data menggunakan uji Chi Square.

Hasil: Sebagian besar responden merupakan laki-laki yaitu sebanyak 173 orang $(87,4 \%)$, responden yang mengalami harga diri rendah sebanyak 70 orang $(35,4 \%)$, orangtua responden yang dominan dalam pemberian pola asuh adalah bapak yaitu 135 orang $(68,2 \%)$, responden yang memiliki pola asuh otoriter sebanyak 33 orang 
Analisa pola asuh orang tua dengan harga diri pada siswa/siswi Sekolah Menengah Atas

$(16,7 \%)$, pola asuh permisif sebanyak 27 orang $(13,6 \%)$, pola asuh diabaikan sebanyak 44 orang $(22,2 \%)$, pola asuh demokratis sebanyak 94 orang $(47,5 \%)$ dan ( $p$-value $=0,000$ dan $O R=4,143),(p$-value $=0,984),(p$-value $=$ $0,000$ dan $\mathrm{OR}=4,100)$, ( $\mathrm{p}$-value $=0,000$ dan $\mathrm{OR}=7,556)$.

Simpulan: Terdapat hubungan pola asuh otoriter, diabaikan dan demokratis dengan harga diri pada siswa di SMK "A" Kota Bandar Lampung Tahun 2019. Tidak terdapat hubungan pola asuh permisif dengan harga diri pada siswa di SMK "A" Kota Bandar Lampung Tahun 2019. Saran : Dalam penelitian ini diharapkan orangtua lebih memahami tentang pentingnya pola asuh yang tepat agar terbentuk harga diri yang tinggi pada anak remaja.

\section{Kata Kunci: Pola Asuh; Harga Diri; Siswa/siswi Sekolah Menengah Atas}

\section{PENDAHULUAN}

Harga diri adalah salah satu konsep diri yang merupakan penilaian pribadi berdasarkan seberapa baik perilaku sesuai dengan ideal diri. Harga diri sangat mengancam pada masa remaja. Hal ini disebabkan karena banyaknya perubahan yang terjadi baik fisik maupun psikososial serta banyak keputusan yang harus dibuat menyangkut dirinya. Apabila remaja tidak dapat melakukan penyesuaian dengan kondisi tersebut, maka akan menyebabkan harga diri rendah. Beberapa masalah yang dapat timbul akibat harga diri pada remaja antara lain gangguan dalam berhubungan, rasa diri penting berlebihan, mudah tersinggung atau marah yang berlebihan, ketegangan peran yang dirasakan (Lelono \& Damayanti, 2015).

World Health Organitation (WHO) mengatakan anak-anak perserikatan bangsa-bangsa, UNICEF, memperkirakan bahwa lebih dari 1 juta anak-anak berada di balik jeruji besi di seluruh dunia dengan kasus kriminilitas. Data peningkatan kenakalan remaja dari tahun ketahun diambil dari Badan Pusat Statistik (BPS), pada tahun 2013 angka kenakalan remaja di Indonesia mencapai 6325 kasus, sedangkan pada tahun 2014 jumlahnya mencapai 7007 kasus dan pada tahun 2015 mencapai 7762 kasus. Artinya dari tahun 2013-2014 mengalami kenaikan sebesar 10,7\%, kasus tersebut terdiri dari berbagai kasus kenakalan remaja diantaranya, pencurian, pembunuhan, pergaulan bebas dan narkoba.Angka pelaku kriminal pada remaja di sumatera barat terdiri dari, narkotika $(46 \%)$, pencurian $(33 \%)$, kekerasan $(11 \%)$, penganiayaan (6\%), dan pelecehan seksual (4\%) (Meilita, 2018).

Bentuk pola asuh orangtua mempengaruhi pembentukan kepribadian anak saat dia dewasa. Hal ini dikarenakan watak seorang individu sebenarnya jauh sebelumnya sudah ditanamtumbuhkan ke dalam jiwa seorang individu sejak sangat awal yaitu pada masa kanak-kanak. Itulah sebabnya pola asuh yang diteapkan oleh orangtua sangan dominan dalam membentuk kepribadian anak sejak kecil hingga dewasa. Pola asuh yang diterapkan orangtua sangat bervariasi seperti otoriter, permisif, demokratis maupun diabaikan (involved). Hal ini dipengaruhi oleh banyak faktor seperti pendidikan orangtua, pekerjaan, sosial ekonomi, suku/ adat serta fenomena perilaku yang diyunjukkan oleh anak (Djamarah, 2014).

Berdasarkan berita pada media online dimana terdapat puluhan pelajar SMK "A" terlibat dalam tawuran dengan siswa SMA lain dan kejadian ini bukan untuk pertama kalinya dilakukan oleh para siswa tetapi sudah berlangsung beberapa kali (Pamungkas, 2018). Pada presurvey yang telah dilakukan oleh peneliti pada 10 siswa di SMK 2 Mei diperoleh bahwa 7 orang $(70 \%)$ mengalami kesulitan dalam menerima materi pelajaran di sekolah, 5 orang (50\%) mengatakan pernah terlibat tawuran dan pernah membolos, 6 orang (60\%) mengatakan tidak memiliki kepercayaan diri dan 7 orang $(70 \%)$ mengatakan orangtua selalu mengambil keputusan sendiri dengan tidak pernah menanyakan pendapat anak terlebih dahulu.

\section{METODE}

Penelitian analitik korelasional, dengan pendekatan Cross Sectional, populasinya siswa kelas X di SMK A Bandar Lampung pada tahun 2019 dan sampelnya sebanyak 198 responden menggunakan metode acak sederhana. Metode pengumpulan data menggunakan kuesioner,

\footnotetext{
Mardhatilah Hasdianasari', Teguh Pribadi ${ }^{2 *}$, Lolita Sary ${ }^{3}$

'Rumah Sakit jiwa Daerah Provinsi Lampung

${ }^{2}$ Program Studi llmu Keperawatan, Fakultas Kedokteran Universitas Mahalayati.

${ }^{3}$ Program Studi Kesehatan Masyarakat, Fakultas Kesehatan Masyarakat Universitas Mahalayati

Korespondensi Penulis: Teguh Pribadi. *Email: teguh@malahayati.ac.id
} 
Analisa pola asuh orang tua dengan harga diri pada siswa/siswi Sekolah Menengah Atas

kuesioner penilaian pola asuh orang tua terdiri atas 18 pertanyaan yang dinilai dalam 1 bulan terakhir.

Penilaiannya dikategorikan menjadi: Pola Asuh Otoriter, Jika jawaban A > 33,3\%; Pola Asuh Permisif, Jika jawaban B > 33,3\%; Pola Asuh Demokratis, Jika jawaban $C>33,3 \%$ : Pola asuh demokratis Jika jawaban $\mathrm{C}<33,3 \%$; dan Pola asuh campuran: bila jawaban pola asuh sama di dua pola asuh atau tiga pola asuh.

Pola Asuh Otoriter a. Sikap "acceptance" rendah, namun kontrolnya tinggi. b. Suka menghukum secara fisik. c. Bersikap mengomando (mengharuskan/memerintah anak untuk melakukan sesuatu tanpa kompromi) . d. Bersikap kaku (keras). e. Cenderung emosional dan bersikap menolak. 2. Pola Asuh Permisif a. Sikap "acceptance " tinggi, namun kontrolnya rendah b. Memberi kebebasan kepada anak untuk menyatakan dorongan/keinginannya 3. Pola Asuh Demokratis a. Sikap "acceptance" dan kontrolnya tinggi b. Bersikap responsif terhadap kebutuhan anak c. Mendorong anak untuk menyatakan pendapat atau pertanyaan $d$. Memberikan penjelasan tentang dampak perbuatan yang baik dan yang buruk (Tridonanto, 2014; Shochib, 2010; Wicaksana, \& Suwartono, 2019)

Penilaian harga diri terdiri dari 10 Item pernyataan dalam kuesioner Rosenberg SelfEsteem (RSE) skala numerik yang dikembangkan oleh Rosenberg (1965) menggunakan skala likert, dengan penilaian untuk pertanyaan sangat setuju (3), setuju (2), tidak setuju (1), dan sangat tidak setuju (0).

Penilaiannya secara kategorik apabila nilai skorenya diatas mean harga diri tinggi begitupun sebaliknya. Uji statistik menggunakan Chi Square Penelitian ini mendapatkan kelaikan etik dari Komisi Etik Penelitian Kesehatan (KEPK) Universitas Malahayati. Nomor Surat No.1019/EC/KEPUNMAL/IX/2019

\footnotetext{
Mardhatilah Hasdianasari', Teguh Pribadi ${ }^{2 *}$, Lolita Sary ${ }^{3}$

'Rumah Sakit Jiwa Daerah Provinsi Lampung

${ }^{2}$ Program Studi llmu Keperawatan, Fakultas Kedokteran Universitas Mahalayati.

${ }^{3}$ Program Studi Kesehatan Masyarakat, Fakultas Kesehatan Masyarakat Universitas Mahalayati

Korespondensi Penulis: Teguh Pribadi. *Email: teguh@malahayati.ac.id
}

DOI: https://doi.org/10.33024/hjk.v15il.1604 
HASIL

Tabel 1. Data Demografi Responden $\mathrm{N}=198$

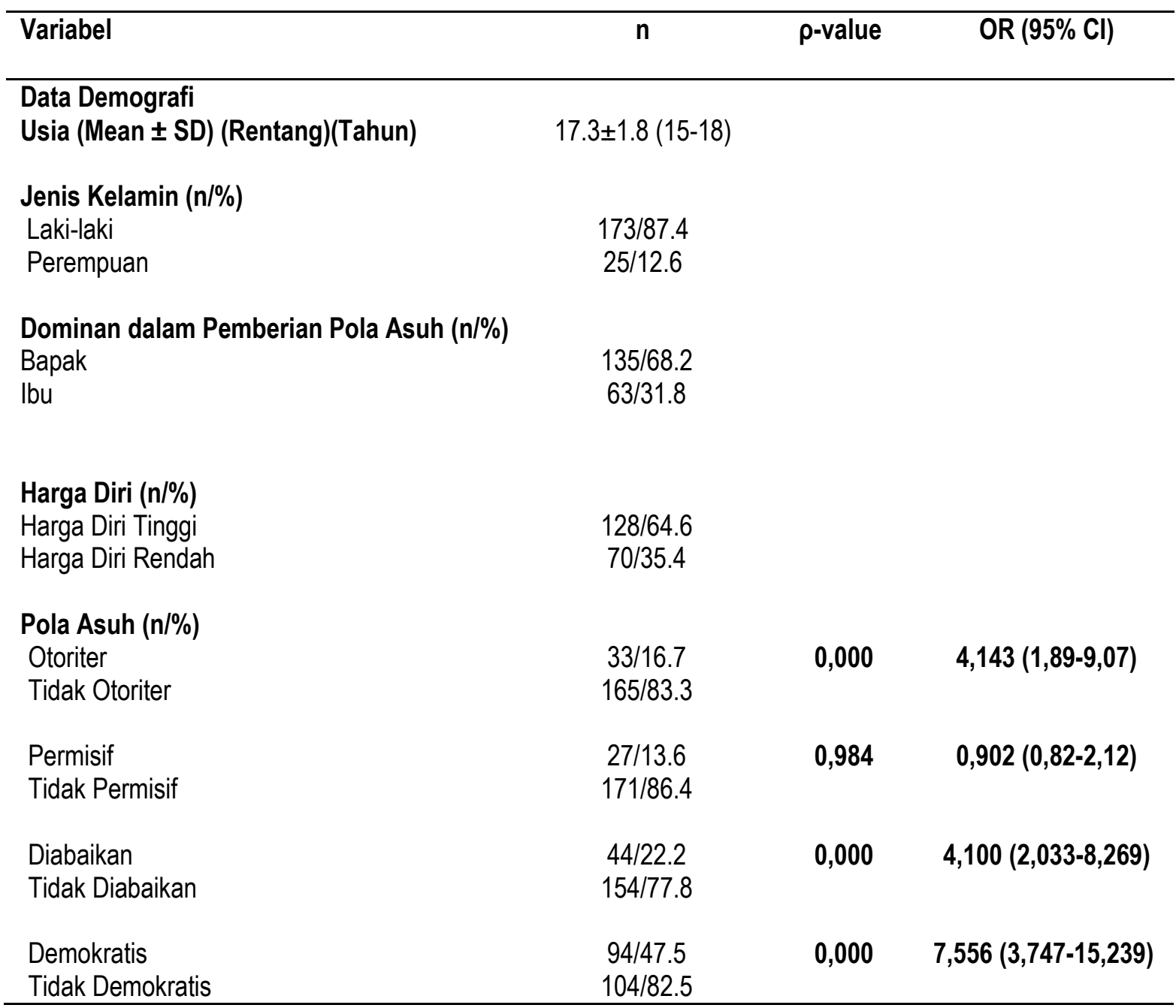

Berdasarkan tabel diatas usia rata-rata 17.3 tahun dengan standar deviasi 1.8 dan rentangnya 15-18 tahun, didominasi berjenis kelamin laki-laki $87.4 \%$. dominasi pola asuh yang didapatkan dalam keluarga didominasi ole bapak sebanyak $68.2 \%$. Harga diri siswa terbanyak dalam kategori tinggi sebesar $64.4 \%$.

Hasil analisa statistic didapatkan: adanya hubungan pola asuh otoriter dengan harga diri didapatkan $p$-value $=0.000$. dan nilai odds ratio $(O R)=4.143$. maka dapat disimpulkan bahwa siswa dengan pola asuh otoriter, memiliki kemungkinan 4 kali untuk mengalami harga diri rendah; tidak ada hubungan pola asuh permisif dengan harga diri didapatkan $p$-value $=0.984$, dan nilai odds ratio $(\mathrm{OR})=0.902$.

Adanya hubungan pola asuh diabaikan, didapatkan $p$-value $=0,000$, dan nilai odds ratio $(O R)=4,100$, maka dapat disimpulkan bahwa siswa dengan pola asuh diabaikan, memiliki kemungkinan 4 kali untuk mengalami harga diri rendah. Adanya hubungan pola asuh tidak demokratis didapatkan $p$-value $=0,000$ dan nilai odds ratio $(\mathrm{OR})=7,556$, maka dapat disimpulkan bahwa siswa dengan pola asuh tidak demokratis,

Mardhatilah Hasdianasari', Teguh Pribadi ${ }^{2 *}$, Lolita Sary ${ }^{3}$

'Rumah Sakit jiwa Daerah Provinsi Lampung

${ }^{2}$ Program Studi llmu Keperawatan, Fakultas Kedokteran Universitas Mahalayati.

${ }^{3}$ Program Studi Kesehatan Masyarakat, Fakultas Kesehatan Masyarakat Universitas Mahalayati

Korespondensi Penulis: Teguh Pribadi. *Email: teguh@malahayati.ac.id

DOI: https://doi.org/10.33024/hjk.v15il.1604 
Analisa pola asuh orang tua dengan harga diri pada siswa/siswi Sekolah Menengah Atas

memiliki kemungkinan 7 kali untuk mengalami harga diri rendah

\section{PEMBAHASAN}

Berdasarkan hasil penelitian diperoleh bahwa sebagian besar responden tidak mengalami harga diri rendah, yaitu sebanyak 128 orang $(64,6 \%)$. Sedangkan responden yang mengalami harga diri rendah, yaitu sebanyak 70 orang $(35,4 \%)$.

Hasil penelitian ini sesuai dengan teori, bahwa harga diri merupakan penilaian pribadi berdasarkan seberapa baik perilaku sesuai dengan ideal diri. Penentuan harga diri seseorang diperoleh dari diri sendiri dan orang lain (dicintai, dihormati, dan dihargai) yang timbul sejak kecil dan berkembang sesuai dengan meningkatnya usia (Lelono, \& Damayanti, 2015; Nora, 2015). Harga diri seseorang diperoleh dari diri sendiri dan orang lain. Gangguan harga diri rendah akan terjadi jika kehilangan kasih sayang, perlakuan orang lain yang mengancam dan hubungan interpersonal yang buruk. Tingkat harga diri seseorang berada dalam rentang tinggi sampai rendah. Individu yang memiliki harga diri tinggi menghadapi lingkungan secara aktif dan mampu beradaptasi secara efektif untuk berubah serta cenderung merasa aman. Individu yang memiliki harga diri rendah melihat lingkungan dengan cara negatif dan menganggap sebagai ancaman (Yosep, 2014; Hidayati, 2016; Vanechia, 2017).

Menurut pendapat peneliti harga diri anak dapa dipengaruhi oleh adanya faktor-faktor dari luar misalnya pola asuh orang tua terhadap anak. Pola asuh merupakan sikap orangtua dalam interaksi dengan anak-anaknya yang meliputi cara orangtua memberikan aturan-aturan, memberikan perhatian dalam rangka memenuhi kebutuhan anaknya. Faktor tersebut diduga mempengaruhi harga diri seseorang anak nantinya, dimana jika hal tersebut tidak segera ditindak lanjuti akan menyebabkan dampak bagi pembentukan konsep diri anak yang kurang baik.

\section{Pola Asuh Otoriter}

Berdasarkan hasil penelitian diperoleh bahwa sebagian sebagian besar responden memiliki memiliki pola asuh tidak otoriter, yaitu sebanyak
165 orang $(83,3 \%)$. Sedangkan responden yang memiliki pola asuh otoriter, yaitu sebanyak 33 orang $(16,7 \%)$.

Hasil penelitian ini sesuai dengan teori bahwa pola asuh otoriter dalah pola asuh yang menekankan dimensi kontrol yang tinggi namun dimensi kehangatannya rendah. Orang tua kerapkali memberlakukan aturan yang tegas kepada anak serta memberlakukan hukuman atas perilaku anak yang dianggap tidak sesuai dengan standar orang tua.Orang tua tampak menjaga jarak kedekatan dengan anak,tidak hangat dan sangat membatasi pertukaran pendapat. Dalam hal ini anak dianggap harus sepenuhnya mematuhi perintah orang tua dan tidak ada penyampaian pendapat anak (Baskoro, 2019; Badiah, 2016).

Menurut pendapat peneliti pola asuh otoriter ditandai dengan cara mengasuh anak dengan menerapkan aturan-aturan yang ketat bagi anak. Sering kali orang tua memaksa anak untuk berperilaku seperti dirinya, kebebasan untuk bertindak mengekspresikan diri sendiri selalu dibatasi. Dengan menerapkan pola asuh otoriter ini yang terkesan bersifat keras, akan berdampak negatif terhadap perkembangan anak.

\section{Pola Asuh Permisif}

Berdasarkan hasil penelitian diperoleh bahwa sebagian besar responden memiliki memiliki pola asuh tidak permisif, yaitu sebanyak 171 orang $(86,4 \%)$. Sedangkan responden yang memiliki pola asuh permisif, yaitu sebanyak 27 orang $(13,6 \%)$. Hasil penelitian ini sesuai dengan teori bahwa pola asuh orang tua adalah upaya orangtua yang konsisten dan persisten dalam menjaga dan membimbing anak dari sejak dilahirkan hingga remaja. Pola asuh orangtua adalah pola perilaku yang diterapkan pada anak dan bersifat relatif konsisten dari waktu ke waktu. Pola perilaku ini dapat dirasakan oleh anak dan bisa beri efek negatif maupun positif (Djamarah, 2014).

Pola asuh permisif merupakan pola asuh yang berkebalikan dengan pola asuh otoriter, yaitu memiliki dimensi kontrol yang rendah dan dimensi kehangatan yang tinggi. Orang tua sangat peduli dengan kebutuhan perasaan anak, akan tetapi kurang memberikan kontrol. Hubungan orang tua dan anak cukup hangat. Orang tua sangat

\footnotetext{
Mardhatilah Hasdianasari', Teguh Pribadi ${ }^{2 *}$, Lolita Sary ${ }^{3}$

'Rumah Sakit jiwa Daerah Provinsi Lampung

${ }^{2}$ Program Studi llmu Keperawatan, Fakultas Kedokteran Universitas Mahalayati.

${ }^{3}$ Program Studi Kesehatan Masyarakat, Fakultas Kesehatan Masyarakat Universitas Mahalayati

Korespondensi Penulis: Teguh Pribadi. *Email: teguh@malahayati.ac.id
}

DOI: https://doi.org/10.33024/hjk.v15il.1604 
Analisa pola asuh orang tua dengan harga diri pada siswa/siswi Sekolah Menengah Atas

memperhatikan kebutuhan anaknya, namun cenderung memanjakan (Baskoro, 2019; Nur, 2015).

Menurut pendapat peneliti pola asuh permisif memiliki ciri yang menuruti keinginan anak dan sangat sedikit aturan terhadap anak. Sering kali orang tua mencintai dan mengekspresikan pola asuh ini terhadap anak-anak mereka, tanpa melihat anak-anak tersebut sudah cukup mampu unuk melaksanakan tugas tertentu. Anak yang dididik dengan pola asuh permisif cenderung tidak disiplin karena orang tuanya menghindari konfrontasi. Orang tua tersebut memilih untuk membiarkan anak-anak mencari tahu sendiri. Tidak sedikit orang tua yang memiliki gaya pengasuhan ini. Orang tua takut menetapkan batas-batas yang jelas dan khawatir anak mereka tidak bahagia. Namun hal tersebut cenderung dapat berubah menjadi gaya pengasuhan yang kurang efektif.

\section{Pola Asuh Diabaikan}

Berdasarkan hasil penelitian diperoleh bahwa sebagian besar responden memiliki memiliki pola asuh tidak diabaikan, yaitu sebanyak 154 orang $(77,8 \%)$. Sedangkan responden yang memiliki pola asuh diabaikan, yaitu sebanyak 44 orang $(22,2 \%)$. Hasil penelitian ini sesuai dengan teori bahwa pola asuh diabaikan merupakan pola asuh dengan orang tua yang tidak memberikan tuntutan apapun kepada anak. Tidak ada standar-standar atau target-target yang harus dicapai anak dalam usia perkembangannya ataupun secara prestasi sekolah. Semua dibebaskan serta tidak ada pengontrolan. Tidak adanya figur yang jelas dari orang tua membuat anak-anak yang dibesarkan dengan pola asuh yang diabaikan ini tidak mengerti mana yang salah dan yang benar. Ketika anak meniru hal buruk dari TV ataupun lingkungan, tidak ada kontrol dari orang tua (Baskoro, 2019; Artha, 2016; Rakhmawati, 2015). Hasil penelitian ini sama dengan penelitian yang dilakukan dengan hasil olah data diperoleh bahwa pola asuh orangtua sebagian besar kategori demokratis yaitu $75,5 \%$ (Haryanti, \& Sutejo 2014).

Menurut pendapat peneliti poa asuh diabaikan merupakan bentuk ketidakpedulian dari orangtua. Mereka tidak mengasuh dan mendidik anak secara langsung. Semuanya dilakukan oleh tangan orang ketiga. Misalnya dengan menyerahkan pengasuhan anak ke babysitter atau mertua dikarenakan orang tua yang fokus mengejar karier dan tidak punya banyak waktu luang bagi anak atau keluarga. Anak yang tumbuh dalam pola asuh seperti ini akan kehilangan sentuhan dan kasih sayang dari orangtuanya sehingga akan mengganggu proses perkembangan kepribadiannya.

\section{Pola Asuh Demokratis}

Berdasarkan hasil penelitian diperoleh bahwa sebagian besar responden memiliki memiliki pola asuh tidak demokratis, yaitu sebanyak 104 orang $(52,5 \%)$. Sedangkan responden yang memiliki pola asuh demokratis, yaitu sebanyak 94 orang $(47,5 \%)$. Hasil penelitian ini sesuai dengan teori bahwa pola asuh demokratis memiliki dimensi kontrol yang tinggi namun juga memiliki dimensi perhatian yang juga tinggi. Anak hidup dalam ketentuan-ketentuan yang harus ia penuhi, namun juga mendapat perhatian dan pemenuhan kebutuhan fisik dan psikologis yang cukup. Pola asuh demokratis menekankan komunikasi dua arah. Artinya, anak tidak hanya menuruti perintah orang tua, akan tetapi juga diberi hak untuk mengutarakan perasaannya (Baskoro, 2019). Hasil penelitian ini sama dengan penelitian sebelumnya yang menunjukkan $71,9 \%$ responden mempunyai pola asuh demokratis (Fitriana, 2017).

Menurut pendapat peneliti pola asuh demokratis memungkinkan orangtua dan anak saling menyesuaikan diri dengan berbagai keadaan dirinya dengan membimbing anak sesuai dengan kemampuan anak tanpa menuntut. Pola asuh demokratis memprioritaskan kepentingan anak tetapi tidak ragu dalam mengendalikan mereka dengan aturan-aturang ang disepakaati bersama. Orang tua seperti ini bersikap rasional dan selalu mendasari tindakannya pada pemikiran. Orang tua tipe ini juga bersikap realistis terhadap kemampuan anak dan juga memberikan kebebasan kepada anak untuk memilih. Mereka juga membebaskan anak dalam memutuskan suatu tindakan. Apabila hendak menasehati, orangtua demokratis selalu melakukannya dengan pendekatan yang baik dan mendidik.

\footnotetext{
Mardhatilah Hasdianasari', Teguh Pribadi ${ }^{2 *}$, Lolita Sary ${ }^{3}$

'Rumah Sakit Jiwa Daerah Provinsi Lampung

${ }^{2}$ Program Studi llmu Keperawatan, Fakultas Kedokteran Universitas Mahalayati.

${ }^{3}$ Program Studi Kesehatan Masyarakat, Fakultas Kesehatan Masyarakat Universitas Mahalayati

Korespondensi Penulis: Teguh Pribadi. *Email: teguh@malahayati.ac.id
} 
Analisa pola asuh orang tua dengan harga diri pada siswa/siswi Sekolah Menengah Atas

\section{Hubungan Pola Asuh Otoriter Dengan Harga Diri}

Berdasarkan hasil penelitian diperoleh bahwa terdapat hubungan pola asuh otoriter dengan harga diri. Hasil penelitian ini sesuai dengan teori, bahwa harga diri rendah sangat berhubungan dengan pola asuh dan kemampuan individu menjalankan peran dan fungsi. Penilaian individu terhadap diri sendiri karena kegagalan menjalankan fungsi dan peran. termasuk dalam harga diri rendah situasional. Harga diri rendah situasional merupakan pengembangan persepsi negatif tentang dirinya sendiri pada suatu. Jika lingkungan tidak memberi dukungan positif atau justru menyalahkan individu dan terjadi secara terus menerus akan mengakibatkan individu mengalami harga diri rendah kronis (Stuart, \& Sundeen, 2015). Tipe pola asuh otoriter adalah tipe pola asuh orang tua yang memaksakan kehendak. Dengan tipe orang tua ini cenderung sebagai pengendali atau pengawas (controller), selalu memaksakan kehendak kepada anak, tidak terbuka terhadap pendapat anak, sangat sulit menerima saran dan cenderung memaksakan kehendak dalam perbedaan, terlalu percaya pada diri sendiri sehingga menutup katup musyawarah. Dalam upaya mempengaruhi anak sering mempergunakan pendekatan (approach) yang mengandung unsur paksaan dan ancaman. Kata-kata yang diucapkan orang tua adalah hukum atau peraturan dan tidak dapat diubah, memonopoli tindak komunikasi dan seringkali meniadakan umpan balik dari anak (Djamarah, 2014). Hasil penelitian ini sama dengan penelitian yang dilakukan oleh bahwa berdasarkan penelitian diperoleh hasil signifikansi antara pola asuh orangtua otoriter dan pola asuh diabaikan dengan harga diri siswa (Haryanti, \& Sutejo, 2014).

Menurut pendapat peneliti hubungan antara pola asuh orangtua dengan harga diri siswa disebabkan karena orang tua yang menerapkan pola asuh otoriter dimana ia akan memaksa anak untuk mengikuti semua yang dikatakan oleh orang tua sehingga membuat anak tidak dapat mandiri sehingga akan mamiliki harga diri yang rendah. Hal tersebut dapat dilihat dari anak dengan pola asuh otoriter cenderung mengalami harga diri rendah
$(63,6 \%)$ sedangkan anak dengan pola asuh tidak otoriter senderung tidak mengalami harga diri rendah $(70,3 \%)$. Anak yang mengalami penerapan pola asuh otoriter ini, akan mengalami harga diri rendah karena dia tidak diberi atau tidak memiliki kesempatan untuk menyampaikan pendapatnya, karena apa yang dia inginkan kemudian dia sampaikan kepada orang tuanya, akan selalu ditolak oleh orang tuanya. Sehingga menjadikan anak tidak percaya pada diri sendiri, karena anak telah terbiasa bertindak harus mendapat persetujuan orang tuanya mengakibatkan anak akan memiliki harga diri rendah.

Selain itu juga diperoleh hasil bahwa terdapat orangtua yang menerapkan pola asuh otoriter tetapi anak remaja tidak memiliki harga diri yang rendah yaitu sebanyak 12 orang $(36,4 \%)$. Menurut peneliti hal ini disebabkan karena anak remaja tersebut memiliki lingkungan yang memberinya dampak positif seperti aktif mengikuti berbagai kegiantan disekolah seperti ekstrakulikuler sehingga remaja memiliki banyak teman-teman yang peduli sehingga remaja menjadi memiliki rasa percaya diri yang tinggi.

Selain itu juga diperoleh bahwa terdapat remaja yang mengalami harga diri rendah meskipun orangtua tidak menerapkan pola asuh otoriter yaitu sebanyak 49 orang $(29,7 \%)$. Menurut peneliti hal ini disebabkan oleh beberapa faktor misalnya remaja merasa tidak memiliki kelebihan atau keterampilan yang dapat dia banggakan seperti kurangnya kemampuan dalam menerima pelajaran. Hal ini dapat menyebabkan remaja menjadi tidak percaya diri atau memiliki harga diri rendah.

\section{Hubungan Pola Asuh Permisif Dengan Harga Diri}

Hasil penelitian ini sesuai dengan teori yang dikemukakan oleh, pola asuh permisif berbanding terbalik dengan pola asuh otoriter, semua dilonggarkan nyaris tidak ada aturan. Orang tua tidak menerapkan batasan, cenderung memberi kebebasan anak mengerjakan apapun semaunya. Hubungan antara anak dan orang tua sangat hangat, karena tidak ada tuntutan apapun pada anaknya. Sistem reward and punishment tidak berlaku efektif, karena anak lebih sering mendapat

\footnotetext{
Mardhatilah Hasdianasari', Teguh Pribadi ${ }^{2 *}$, Lolita Sary ${ }^{3}$

'Rumah Sakit Jiwa Daerah Provinsi Lampung

${ }^{2}$ Program Studi llmu Keperawatan, Fakultas Kedokteran Universitas Mahalayati.

${ }^{3}$ Program Studi Kesehatan Masyarakat, Fakultas Kesehatan Masyarakat Universitas Mahalayati

Korespondensi Penulis: Teguh Pribadi. *Email: teguh@malahayati.ac.id
} 
Analisa pola asuh orang tua dengan harga diri pada siswa/siswi Sekolah Menengah Atas

reward dibanding hukuman. Pola asuh permisif atau serba boleh, biasanya membuat anak maunya menang sendiri. Selain itu menjadi anak tidak percaya diri, tumbuh menjadi pribadi kurang mandiri atau sangat tergantung. Semua sebagai dampak kurangnya bimbingan dan arahan, sehingga anak kurang dilatih bertanggung jawab. Anak dengan pola asuh permisif, akan mengalami masalah ketika remaja atau jelang dewasa. Mereka yang seharusnya bisa menyelesaikan urusan sendiri, tapi masih sangat mengandalkan orang lain (Djamarah \& Bahri, 2014). Hasil penelitian ini tidak sama dengan penelitian yang dilakukan sebelumnya, dimana hasil penelitian ini ada hubungan yang signifikan antara persepsi pola asuh permisif dan pola asuh demokratis dengan harga diri remaja (Fitriana, 2017).

Menurut pendapat peneliti, tidak terdapat hubungan pola asuh permisif dengan harga diri pada siswa disebabkan karena secara umum pola asuh permisif digunakan cenderung membuat anak menjadi manja, egois, tidak disiplin, dan mudah menyerah. Berkaitan dengan harga diri, pola asuh ini kurang dominan dalam mempengaruhi terjadinya harga diri rendah, karena justru penerapannya membuet anak manja atau terlalu egois karena permintaannya yang selalu dituruti. Orang tua dengan pola asuh permisif terlalu memberi kebebasan terhadap apa yang dilakukan anak sehingga anak cenderung mengikuti keinginannya sendiri yang menurut ia baik.

\section{Hubungan Pola Asuh Diabaikan Dengan Harga Diri}

Hasil penelitian ini sesuai dengan teori, bahwa dibanding semua pola asuh yang ada, pola asuh diabaikan ini adalah yang paling buruk. Pola asuh ini dikatakan paling buruk karena memiliki dua dimensi yang sama-sama rendah. Artinya pola asuh ini tidak memberikan kontrol namun juga tidak memberikan kehangatan bagi anak. Orang tua tidak hadir dan tidak dirasakan berperan banyak di kehidupan anak. Mereka (orang tua) tidak peka dengan kebutuhan fisik maupun psikologis anak serta menarik diri secara emosional. Saat anak merasa kesusahan, orang tua tidak tanggap dan tidak berusaha menunjukkan kepeduliannya, sehingga hal ini membuat anak merasa tidak dimengerti oleh orang tuanya (Baskoro, (2019). Hasil penelitian ini sama dengan penelitian yang dilakukan oleh, bahwa berdasarkan penelitian diperoleh hasil signifikansi antara pola asuh orangtua dengan harga diri siswa (Haryanti, \& Sutejo, 2014).

Menurut pendapat peneliti adanya hubungan pola asuh diabaikan dengan harga diri dapat disebabkan pola asuh diabiikan yaitu dengan pengabaian anak secara fisik ataupun emosional seperti mengabaikan kebutuhannya atau membuat anak merasa tidak berharga sehingga memiliki harga diri yang rendah. Hal tersebut dapat dilihat dari anak dengan pola asuh diabaikan cenderung mengalami harga diri rendah $(61,4 \%)$ sedangkan anak dengan pola asuh tidak diabaikan cenderung tidak mengalami harga diri rendah $(72,1 \%)$.

Berdasarkan hasil penelitian juga diperoleh bahwa teradpat remaja yang memiliki pola asuh tidak diabaikan tetapi memiliki harga diri rendah yaitu sebanyak $43(27,9 \%)$. Menurut peneliti harga diri rendah yang dialami remaja disebabkan oleh faktor lain seperti remaja merasa dirinya tidak sepadan dengan teman sebayanya seperti dalam hal bentuk fisik, penampilan atau dalam kemampuan menerima pelajaran di sekolah.

Selain itu juga terdapat remaja yang memiliki pola asuh diabaikan tetapi remaja tersebut tidak mengalami harga diri rendah yaitu sebanyak 17 orang $(38,6 \%)$. Menurut peneliti hal ini disebabkan karena remaja mendapatkan perhatian dan kasih saying dari lingkungan lainnya seperti dari teman sekolah. Remaja yang memiliki teman sebaya yang peduli dan memberikan kasih saying yang baik akan membuat remaja menjadi percaya diri dan merasa disayangi.

\section{Hubungan Pola Asuh Demokratis Dengan Harga Diri}

Hasil penelitian ini sesuai dengan teori bahwa pola asuh demokratis merupakan pola asuh yang selalu mendahulukan kepentingan bersama diatas kepentingan indivisu anak. Tipe ini adalah tipe pola asuh orangtua yang tidak banyak menggunakan kontrol terhadap anak (Baskoro, 2019). Tipe pola asuh demokratis mengharapkan anak untuk berbagi tanggung jawab dan mampu

\footnotetext{
Mardhatilah Hasdianasari', Teguh Pribadi ${ }^{2 *}$, Lolita Sary ${ }^{3}$

'Rumah Sakit jiwa Daerah Provinsi Lampung

${ }^{2}$ Program Studi llmu Keperawatan, Fakultas Kedokteran Universitas Mahalayati.

${ }^{3}$ Program Studi Kesehatan Masyarakat, Fakultas Kesehatan Masyarakat Universitas Mahalayati

Korespondensi Penulis: Teguh Pribadi. *Email: teguh@malahayati.ac.id
} 
Analisa pola asuh orang tua dengan harga diri pada siswa/siswi Sekolah Menengah Atas

mengembangkan potensi kepemimpinan yang dimilikinya. Memiliki kepedulian terhadap hubungan antarpribadi dalam keluarga. Meskipun tampak kurang terorganisasi dengan baik, namun gaya ini dapat berjalan dalam suasana yang rileks dan memilik keceriderungan untuk menghasilkan produktivitas dan kreativitas, karena tipe pola asuh demokratis ini mampu memaksimalkan kemampuan yang dimiliki anak (Pramawaty \& Hartati, 2012).

Menurut pendapat peneliti adanya hubungan pola asuh demokratis dengan harga diri pada siswa disebabkan oleh orang tua ang menerapkan pola asuh demokratis akan memberikan kebebasan kepada anak untuk memilih dan juga membebaskan anak dalam memutuskan suatu tindakan, sehingga anak memiliki rasa percaa diri yang tinggi. Hal tersebut dapat dilihat dari anak dengan pola asuh tidak demokratis, cenderung mengalami harga diri rendah $(54,8 \%)$ sedangkan anak dengan pola asuh demokratis, cenderung tidak mengalami harga diri rendah (86,2\%). Dalam perkembanganya, anak memerlukan suatu arahan dari orang tua dimana arahan tersebut tidak terkesan memaksa dan juga tidak pula memanjakan sang anak, karena pada usia anakanak sudah mulai berfikir dan mampu memahami bagaimana cara orang tua dalam memberi bimbingan serta mengajarkan anak nilai-nilai yang baik dalam kehidupan, oleh karena itu yang paling cocok diterapkan adalah pola asuh demokratis. Pola asuh demokratis akan berdampak baik terhadap perilaku sikap anak, karena pola asuh yang demokratis akan mengarahkan setiap sikap dan perilaku anak dengan menekankan peraturan yang harus dilakukan terhadap pola makan anak. Pola asuh demokratis akan mendorong anak untuk mandiri tetapi tetap menetapkan batas-batas dan pengendalian atas tindakan mereka yang dianggap orang tua tidak baik sehingga akan menjadikan anak lebih mandiri dan memiliki harga diri yang baik.

Berdasarkan hasil penelitian juga diperoleh bahwa terdapat remaja yang memiliki pola asuh demokratis tetapi memiliki harga diri rendah yaitu sebanyak 13 orang $(13,8 \%)$. Menurut peneliti hal ini disebabkan karena harag diri rendah tidak hanya dipengaruhi oleh pola asuh orangtua saja.
Penampilan fisik yang dinilai kurang menarik seperti mendapat ejekan karen memiliki tubuh yang pendek, kulit yang hitam atau hal serupa dapat membuat remaja menjadi tidak percaya diri dan mengalami harga diri rendah.

Selain itu juga terdapat remaja yang tidak memiliki pola asuh demoktaris akan tetapi remaja tidak mengalami harga diri rendah yaitu sebanyak 47 orang $(45,2 \%)$. Menurut peneliti hal ini dapat disebabkan karena remaja memiliki kepercayaan yang tinggi. Hal ini dapat terjadi jika remaja merasa dirinya memiliki kelebihan atau keterampilan yang dapat dibanggakan seperti selalu mendapat nilai ujian yang baik atau memenangkan berbagai perlombaan antar sekolah. Hal positif seperti itu dapat memingkatkan rasa percaya diri remaja karena remaja akan merasa dia dapat melakukan hal positif yang tidak semua orang dapat melakukannya.

\section{SIMPULAN}

Sebagian besar jenis laki-laki sebanyak 173 orang $(87,4 \%)$, Sebagian dominan dalam pemberian pola asuh adalah bapak yaitu 135 orang $(68,2 \%)$,dan memiliki pola asuh demokratis sebanyak 94 orang $(47,5 \%)$, terdapat hubungan pola asuh otoriter dengan harga diri, dan tidak terdapat hubungan pola asuh permisif dengan harga diri. Terdapat hubungan pola asuh diabaikan dengan harga diri dan terdapat hubungan pola asuh demokratis dengan harga diri.

\section{SARAN}

Dapat menambah pengetahuan orangtua mengenai masalah yang terjadi pada anak remaja sehingga dapat menyelesaikannya dengan kekeluargaan seperti rapat wali murid.pola asuh yang baik menurut peneliti adalah pola asuh demokratis dimana dalam penerapannya orang tua dan anak berperan dalam pengambilan keputasan dangan musyawarah bersama sehingga dapat membantuk anak dalam kepercayaan dirinya dan memberi anak tanggang jawab kepada pilihan yang telah ditentukan, dapat menambah pengetahuan dan informasi pada ibu tentang pola asuh yang sangat berhubungan dengan harga diri siswa.

\footnotetext{
Mardhatilah Hasdianasari', Teguh Pribadi ${ }^{2 *}$, Lolita Sary ${ }^{3}$

'Rumah Sakit Jiwa Daerah Provinsi Lampung

${ }^{2}$ Program Studi llmu Keperawatan, Fakultas Kedokteran Universitas Mahalayati.

${ }^{3}$ Program Studi Kesehatan Masyarakat, Fakultas Kesehatan Masyarakat Universitas Mahalayati

Korespondensi Penulis: Teguh Pribadi. *Email: teguh@malahayati.ac.id
} 
Analisa pola asuh orang tua dengan harga diri pada siswa/siswi Sekolah Menengah Atas

Peningkatkan peran petugas kesehatan dalam mengatasi masalah harga diri dengan melakukan edukasi pada orang tua dalam rangka menambahkan pengetahuan tentang penerapan pola asuh yang baik bagi anaknya, menjadi sarana dan refrensi bagi pihak pendidik/ sekolah dalam mengatasi masalah harga diri remaja dengan melakukan edukasi pada orang tua dalam rangka menambah pengetahuan tentang penerapan pola asuh yang baik bagi anaknya, dan dapat memberikan informasi dan menjadi refrensi yang akan menambah literatur mengenai hubungan pola asuh orang tua dengan harga diri pada siswa, dan bagi peneliti selanjutnya agar dapat meningkatkan hasil penelitian dengan memperluas subjek penelitian atau dengan mengambil variabel yang belum diteliti dalam penelitian ini.

\section{DAFTAR PUSTAKA}

Artha, D. J. (2016). Pengaruh pemilihan tayangan televisi terhadap perkembangan sosialisasi anak. EduTech: Jurnal IImu Pendidikan dan IImu Sosial, 2(1).

Badiah, Z. (2016). Peranan Orang Tua dalam Mengembangkan Kecerdasan Emosional dan Spiritual (ESQ) Anak dalam Perspektif Islam. MUDARRISA: Jurnal Kajian Pendidikan Islam, 8(2), 229-254.

Baskoro, D. (2019). Menjadi lebih baik (Parent Healing) cara memperbaiki kesalahan fatal orang tua dalam mendidik anak. Jakarta: PT.Alex Media Komputindo.

Djamarah, S. B. (2014). Pola asuh orang tua dan komunikasi dalam keluarga. Jakarta: Rineka Cipta.

Djamarah. \& Bahri, S. (2014). Upaya membangun citra membentuk pribadi anak. Jakarta: Rineka Cipta.

Fitriana, L. B. (2007). Hubungan persepsi pola asuh dengan harga diri remaja di SMA Negeri 2 Kecamatan Pedurungan Kota
Semarang (Doctoral dissertation, Diponegoro University).

Haryanti, D., \& Sutejo, S. (2014). Hubungan pola asuh orang tua dengan harga diri siswa di SMAN 1 Kretek Bantul (Doctoral dissertation, STIKES'Aisyiyah Yogyakarta).

Hidayati, N. W. (2016). Hubungan harga diri dan konformitas teman sebaya dengan kenakalan remaja. Jurnal Penelitian Pendidikan Indonesia, 1(2).

Lelono, S. K.\& Damayanti, R. (2015). Buku Ajar Keperawatan Jiwa. Lampung: LP2M Institut Agama Islam Negeri Raden Intan Lampung.

Meilita, Z. (2018). Cognitive behavior therapy terhadap harga diri remaja di lembaga pembinaan khusus anak (LPKA). Afiat, 4(02), 593-602.

Nora, M. O. (2015). Pengaruh kelekatan dan harga diri terhadap kemampuan bersosialisasi anak. Jurnal Pendidikan Usia Dini, 9(2), 379388.

Nur, C. M. (2015). Reformulasi konsep pendidikan anak berbasis prophetic parenting.

Pamungkas, S. (2018). Tawuran Pelajar SMKN 4 VS SMK 2 Mei Bandar Lampung 1 Siswa Diamankan Polisi. Kumpas Tuntas Diakses :https://www.kupastuntas.co/2018/05/28/tawura n-pelajar-smkn-4-vs-smk-2-meibandarlampung-satu-siswa-diamankan-polisi/

Pramawaty, N., \& Hartati, E. (2012). Hubungan pola asuh orang tua dengan konsep diri anak usia sekolah (10-12 tahun). Jurnal Keperawatan Diponegoro, 1(1), 87-92.

Rakhmawati, I. (2015). Peran keluarga dalam pengasuhan anak. Jurnal Bimbingan Konseling Islam, 6(1), 1-18.

\footnotetext{
Mardhatilah Hasdianasari', Teguh Pribadi ${ }^{2 *}$, Lolita Sary ${ }^{3}$

'Rumah Sakit Jiwa Daerah Provinsi Lampung

${ }^{2}$ Program Studi llmu Keperawatan, Fakultas Kedokteran Universitas Mahalayati.

${ }^{3}$ Program Studi Kesehatan Masyarakat, Fakultas Kesehatan Masyarakat Universitas Mahalayati

Korespondensi Penulis: Teguh Pribadi. *Email: teguh@malahayati.ac.id
}

DOI: https://doi.org/10.33024/hjk.v15il.1604 
Analisa pola asuh orang tua dengan harga diri pada siswa/siswi Sekolah Menengah Atas

Rosenberg, M. (1965). Rosenberg self-esteem scale (RSE). Acceptance and commitment therapy. Measures package, 61(52), 18.

Shochib, M. (2010). Pola Asuh Orang Tua (Edisi Revisi). Jakarata: PT Rineka Cipta.

Stuart, G. W., \& Sundeen, S. J. (2015). Buku saku keperawatan jiwa. Jakarta: EGC.

Tridonanto, A. (2014). Mengembangkan pola asuh demokratis. Elex Media Komputindo.

Vanechia, S. J. (2017). Hubungan harga diri dengan perilaku bullying pada siswa SMKN 8 Padang Tahun 2017 (Doctoral dissertation, Universitas Andalas).
Wicaksana, D., \& Suwartono, C. (2019). Uji Validitas Dan Reliabilitas Alat Ukur Indonesia Implicit Self-Esteem Test. JP3I (Jurnal Pengukuran Psikologi dan Pendidikan Indonesia), 1(4).

Yosep, I. (2014). Keperawatan Jiwa. Bandung: Refika Aditama. 